\title{
Assessment of The Two Most Watched Films In 2019 In Terms of The Learning Outcomes for The Secondary Education Religious Culture and Moral Knowledge Course
}

\author{
Research Article
}

\section{Veda YAR YILDIRIM1}

${ }^{1}$ Kahramanmaras Sutcu Imam University, Faculty of Education, Department of Educational Sciences, ORCID: 0000-0002-2129-4189

To cite this article: Yar Yildirim, V. (2020). Assessment of The Two Most Watched Films in 2019 in Terms of The Learning Outcomes for The Secondary Education Religious Culture and Moral Knowledge Course, International Online Journal of Educational Sciences, 12(3), 68-80.

ARTICLE INF
Article History:
Received: 02.01.2020
Available online:
22.06.2020

\begin{abstract}
The aim of this study was to assess the positive and negative aspects of scenes and dialogues in the three most watched Turkish films of the previous year in terms of the "moral learning outcomes "required in the secondary curriculum for the Religious Education and Moral Knowledge course. In the research, the case study approach, one of the qualitative research designs, was used, and document analysis was conducted. The criterion sampling method, one of purposeful sampling methods used in qualitative research, was used in order to determine the sample of the research. In this study, the criterion was the number of tickets sold and the three most watched films in 2019 in Turkey were examined. These data were obtained from the "Box Office Turkey" organization. It was decided to reduce the number of films to two to eliminate the possibility of bias. It was concluded that there were both positive and negative scenes and dialogues in the films, but the total number of negative scenes and dialogues was more than that of positive scenes and dialogues. It was observed that the use of slang in the films was most incompatible with the moral learning outcomes. Given these results, activities to increase the awareness of families and educational professionals about the impact of the external world on education could be conducted. The Board of Education and Discipline could also promote films that offer more fertile ground for moral learning outcomes.
\end{abstract}

(C) 2020 IOJES. All rights reserved

Keywords:

Curriculum, morality, learning outcomes, cinema

\section{Introduction}

Education involves, among its other aspects, the process of shaping a human being into someone who has strong moral values (TDK, 2020). The fundamental tenet of morality is that all people are valuable. Being

\footnotetext{
${ }^{1}$ Corresponding author's address: Kahramanmaras Sutcu Imam University, Faculty of Education Telephone: 3443004464

e-mail: vedayaryildirim@gmail.com

DOI: https://doi.org/10.15345/iojes.2020.03.006
} 
able to act in a moral way is generally considered a worthwhile and useful characteristic (TDK, 2015), and a person's morality can be defined as the sum of their choices, opinions, beliefs and behaviours throughout their lives (Erdem, 2003; Özgener, 2004). Moral values make people human, differentiate human beings from other living creatures and promote qualities such as honesty, kindness, tolerance etc. (Kuçuradi, 1995). This aspect of human life has not been left to chance within most educational systems and has been reflected in their objectives.

The general objectives of the Turkish National Education system include many significant values that students should acquire. By upholding such important values as "educating individuals to be people who have personalities and characteristics that are physically, mentally, morally, spiritually and emotionally balanced and healthy; who are able to think freely and in a scientific manner; who have broad perspectives; who are respectful of human rights; who are able to show initiative; who feel responsibility towards society, and who are constructive, creative and productive", the Turkish Education System aims not only to create "good people" and "good citizens" but also makes the effort to ensure that students acquire the aforementioned values at all education levels (National Education Basic Law No. 1739, 1973). It is thus important to create an environment in which values can be sensitively discussed throughout life as a whole, instead of only focusing on values in a single course. Education is above all a service to humanity; it is a culturally constructed system which helps people understand all aspects of life in a humane manner, forms them into morally good people and aims to make them open to all aspects of life (Can and Y1ldırım, 2019).This definition emphasizes the human-made aspect of education. Human beings build schools, prepare curricula and are responsible for the other variables involved, and all of these have positive or negative effects on how people learn and grow.

The formal aspect of education is represented by schools and the curricula, while all the processes that occur outside the school can be regarded as informal modes of education. In educating someone, all these processes need to be consistent and to support each other. The aim of this study was thus to examine the correspondence between the curricula applied in schools and a number of contemporary films, on the basis that film is a major art form which plays a large role in, and has an impact on, many people's lives.

Cinema is considered to be the $7^{\text {th }}$ art (Gök, 2007; Okur, Sügüumlü and Göçen, 2013; Vincenti, 1993) and the one that has most impact (Nowell-Smith, 1996). Films are powerful tools for disseminating cultural norms, influencing people's actions and shaping how they think (Elmac1, 2013; Yanmaz, 2011). To give several examples from studies addressing the impact of cinema on human life: the number of visitors to the ancient city of Troy doubled after the film Troy (Yanmaz, 2011); scenes of people smoking have a $4.2 \%$ effect in making people who watch film start smoking (Yolcu, 2007); films adapted from books encourage students to read (Okur, Süğümlü and Göçen, 2013), and films about teaching positively contribute to the professional lives of prospective teachers and teachers (Kaşkaya, Ünlü, Akar and Sağırlı, 2011; Oruç and Sarıbudak, 2015). These studies show that cinema has an undeniable effect on human life. Films also generally feature, in addition to the plot, elements such as sound design, visual effects and music which increase their impact. In this respect, films offer people an imaginary world that goes beyond everyday experiences, and their influence can wideranging.

The aim of this study was to examine the three most watched Turkish films in 2019 in terms of the learning outcomes given in the secondary education curriculum for the Religious Culture and Moral Knowledge Course prepared by the Turkish Board of Education and Discipline (TTK). The curriculum was prepared according to the "General Objectives of Turkish National Education" and the "Basic Principles of Turkish National Education", which are given in Article 2 of the National Education Basic Law No. 1739. This intends for all educational programs and curricula to be conducted within a framework of moral values and in a complementary manner throughout preschool, primary and secondary education. The "core values" 
included in the curricula are justice, friendship, honesty, self-control, patience, respect, love, responsibility, patriotism, and helpfulness (TTK, 2018).

As per the General Objectives and Basic Principles of Turkish National Education stated in the law, the curriculum for the Religious Culture and Moral Knowledge Course for secondary education (Grades 9-12) aims to enable students to:

(1) understand religious and moral concepts and realize the relation between them, (2) learn national, moral, human and cultural values, (3) learn the basic sources of the religion of Islam, (4) comprehend the place of the prophet Muhammad in Islam, (5)analyse the relationship between the faith, worship and moral principles in Islam, (6) understand the effects of Islam on our culture, language, art, traditions, (7) learn about some important figures who affected the formation of Turkish-Islamic culture, (8) recognize different understandings and interpretations of Islamic thought, (9) learn about the living world religions, (10) respect different religions, beliefs and interpretations, and (11) realize that the religion is an important factor in the relations between people, societies and nations.

In the curriculum for Religious Culture (Grades 9-12) implemented in secondary education, there are five learning outcomes for Moral Attitudes and Behaviours to be covered in 12course hours, which correspond to $16.66 \%$ of the program. The explanations about the learning outcomes stated in the program are as follows:

10.4.1. The subject and purpose of Islamic morality are explained.

10.4.2. The relationship between morality and discipline are explained. Topics such as managing emotions, thoughts, behaviours, and desires are discussed in connection with verses and hadiths.

10.4.3. Some behaviours criticized in Islamic morality are discussed within the framework of verses and hadiths. In this regard, lies and slander, invasion of privacy (espial), gossip, jealousy, suspicion, fraud and wastage are addressed. Activities are carried out in order that students are able to evaluate the individual and social harms of various behaviours criticized in Islamic morality.

10.4.4. The importance of being prudent in attitudes and behaviours is expressed (TTK, Religious Culture and Moral Course Curriculum, 2018).

Examining these learning outcomes, it can be seen that they include teaching about both positive and negative aspects of morality, as expressed through people's words and actions. This study thus aimed to evaluate both the positive and negative aspects of scenes and dialogues in the three most watched Turkish films of 2019 in terms of the moral learning outcomes included in the secondary curriculum for the Religious Education and Moral Knowledge Course.

\section{Method}

\section{Research Model}

The three most watched films in Turkey in 2019, Miracle in Cell No 7, Recep Ivedik 6 and Money Trap were examined in terms of whether their scenes and dialogues were compatible or incompatible with the moral learning outcomes included in the secondary curriculum for the Religious Culture and Moral Course. A case study design, one of the qualitative research models, was used. "A case study is a research method based on answering 'how' and 'why' questions, and it allows the researcher to examine in depth a phenomenon or a case that cannot otherwise be investigated" (Yıldırım and Şimşek, 2008). In this regard, document analysis 
was used as the data collection method in this study. Document analysis usually involves the analysis of written materials that contain information about the phenomenon or phenomena studied. However, visual materials such as films, videos and photos may also be used for this form of qualitative research and can function as the main data collection tools for research. (Yıldırım and Şimşek, 2008).

\section{Research Sample}

The criterion sampling method, one of the purposeful sampling types used in qualitative research, was used in order to determine the sample of the research. The basic aim of this method is to study all situations that meet certain predetermined criteria. In this study, the criterion was the number of cinema tickets sold. These data were obtained from Box Office Turkey in order to determine which were the three most watched films in 2019 in Turkey. In cinema, the term "box office" usually refers to how many tickets a film sells and the total sales it makes from its screenings (Box Office, 2019). The necessary permission was obtained from Box Office Turkey for the use of information. Table 1 shows the most watched films in Turkey in 2019 according to data provided by Box Office Turkey.

Table 1. The most watched Turkish films in 2019

\begin{tabular}{llllll}
\hline No & Name of film & Release date & $\begin{array}{l}\text { Total weeks in } \\
\text { theatres }\end{array}$ & $\begin{array}{l}\text { Number of } \\
\text { theatres }\end{array}$ & $\begin{array}{l}\text { Number of tickets } \\
\text { sold in 2019 }\end{array}$ \\
\hline 1 & Miracle in Cell no. 7 & 11.10 .2019 & 12 & 880 & $5,310,542$ \\
2 & Recep Ivedik 6 & 08.11 .2019 & 8 & 1500 & $3,975,135$ \\
3 & Money Trap & 01.02 .2019 & 10 & 1400 & $3,537,429$ \\
\hline
\end{tabular}

(https://boxofficeturkiye.com/turk-filmleri/?yl, 2019)

Information about the films examined in the study is given in Table 1. The most watched film in 2019 in Turkey was Miracle in Cell No 7. This was followed by Recep Ivedik 6 and Money Trap. In order to eliminate bias, Recep Ivedik 6 was not analysed as its content was already known to the researcher. Probable bias is one of the weaknesses of document analysis. Many documents subject to social research can be analysed in a biased way. Events might have been exaggerated by those who created the document. The inclusion of such documents in the research inevitably affects the results obtained in an adverse manner (Yildırım and Şimşek, 2008). Also, there are different studies investigating the effects of different films in the Recep Ivedik film series on the educational and sociological structure (Alp and Turan, 2019; Büyükokutan Töret, 2014; Geçgin, 2018; Özbulduk Kılıç, 2018; Saral Güneş \& Yağ1z Baylan, 2016). For these reasons, Recep Ivedik 6 was excluded from the research. All analyses were conducted on the first- and third-most watched films in the list.

\section{Data Collection Tools}

In this study, the document analysis method, which is one of the qualitative research methods, was used to assess the three most watched films in Turkey in 2019 in terms of the moral learning outcomes of the secondary Religious Culture and Moral Knowledge Course. To this end, the films Miracle in Cell No 7 and Money Trap were watched.

Miracle in Cell No 7 is set in an Aegean town in 1983. It is a drama about the pursuit for justice of a man named Memo, who is a resident of the town and lives with his grandmother and his 7-year-old daughter but has the same mental age as his daughter. The daughter of the martial law commander dies in the town. Memo is blamed for the death of the little girl. Although Memo says repeatedly that he is innocent, no one but his daughter believes him. Relatives of Memo, who is sentenced to death, strive for justice. The only wish of Memo and her daughter Ova is to meet. The film is an adaptation from a South Korean film with the same title Miracle in Cell No 7. The cast of the film include Aras Bulut İynemli, Nisa Sofiya Aksongur, Celile Toyon, İlker Aksum, Mesut Akusta, Deniz Baysal and Yurdaer Okur. It was directed by Mehmet Ada Öztekin. The film is 2 hours 
and 12 minute long (http://www.beyazperde.com/filmler/film-275065/, 2019). It received a "13+" classification rating (https://biletinial.com/, 2019).
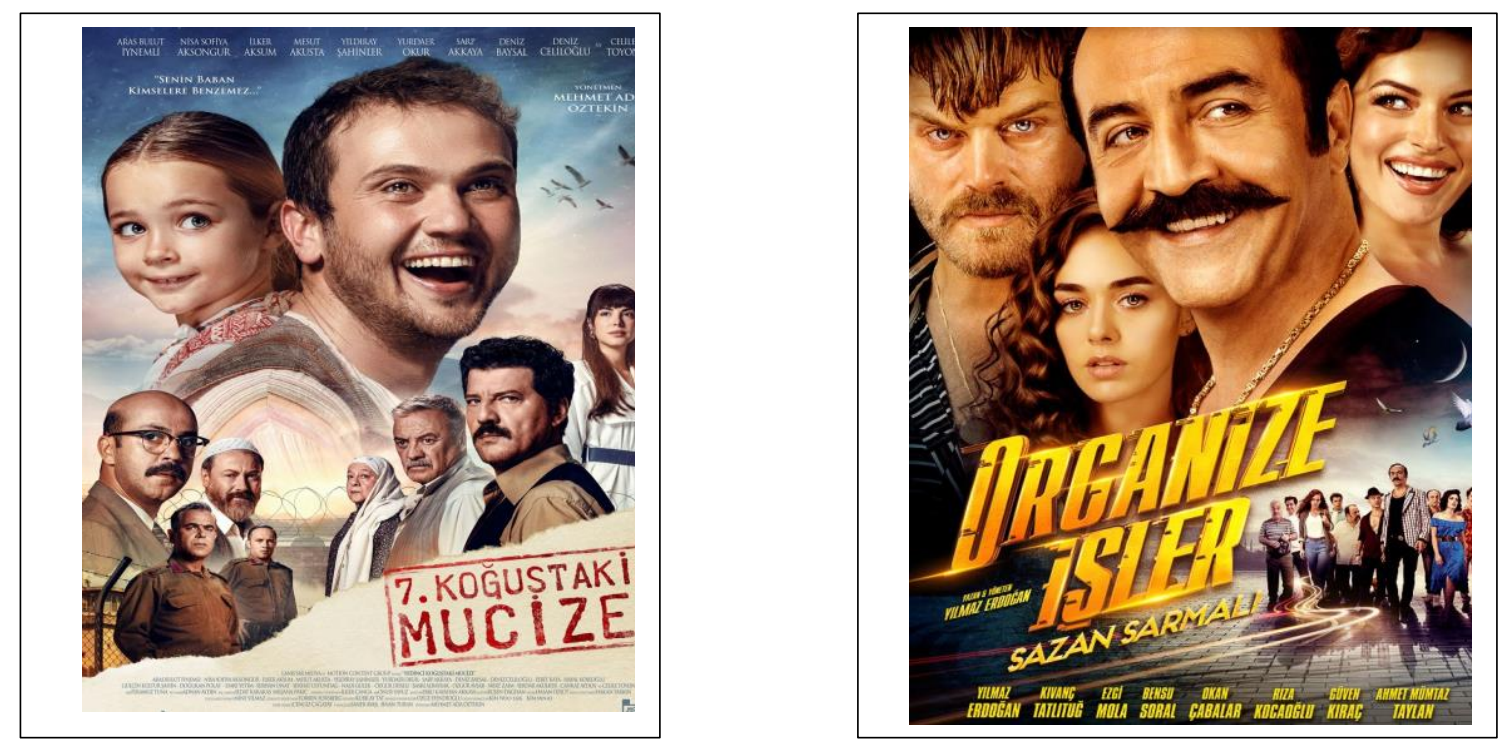

(http://www.beyazperde.com/, 2020)

Money Trap is an action comedy and is the sequel to the film Organized Works. This film is about the story of Asım Noyan, the cheater, and his gang. The organized works (fraud) continues non-stop in İstanbul. Asım Noyan continues his lies that he has been telling for years and cheats people with new tricks. As the security forces have not yet managed to catch Asım Noyan and his gang, they embark on a new trick they call the "money trap" this time. Asım Noyan and his gang take action when another gang of cheaters deceives Nazlı, daughter of Asım Noyan. While Nazlı tries to discourage his father from fraud, she finds herself in an organized fraud.Yılmaz Erdoğan, KıvançTatlıtuğ, Ezgi Mola, Bensu Soral, Rıza Kocaoğlu, Okan Çabalar, Güven Kıraç, Ahmet Mümtaz Taylan, Ersin Korkut, Erdem Baş, Mahir İpek, Ekin Türkmen, Atakan Çelik and Safa Sarı are among the members of the cast. The film is 2 hours and 1 minute long, and was directed by Yilmaz Erdoğan (http://www.beyazperde.com/filmler/film-275065/, 2019). This film receives a "16+" classification rating (https://www.netflix.com, 2019).

The films were watched in order to assess which dialogues and scenes were compatible or incompatible with the learning outcomes of the Religious Culture and Moral Knowledge course. The researcher had previously watched the films so the analysis could begin immediately. Miracle in Cell No 7, which lasts 2 hours and 12 minutes, was reviewed for a period of 14 hours and 13 minutes, and Money Trap, which lasts 2 hours and 1 minute, was reviewed for a period of 15 hours and 20 minutes. It thus took 29 hours 33 minutes for the researcher in total to analyse the films, which have a total running time of 4 hours 13 minutes.

In the course of the study, an attempt was first made to ensure validity and reliability of the study by explaining the research process in detail from the preparation of the data collection tool to its implementation and analysis. Then, the results of the research were shared with academic colleagues and their opinions were sought. Thirdly, the raw data were given to another researcher in the field for peer observation, and he/she was asked to create themes and coded opinions. At this point, the reliability formula proposed by Miles and Huberman (1994) was used: Reliability $=$ [Consensus / (Consensus + Difference of Opinion) $] \times 100$. It was observed that the contents created by the primary researcher and the secondary researcher overlapped by $82 \%$ in terms of positive/negative scenes, and $87 \%$ in terms of positive/negative dialogues, and that they were quite close to each other. Therefore, the results were confirmed. Finally, the results were compared with those of other studies conducted in the same field (Yıldırım and Şimşek, 2008). 


\section{Data Analysis}

The data used in the research was obtained through document analysis. The data obtained were analysed through descriptive analysis. Documents can serve as all the data for a research study (Yıldırım and Şimşek, 2008). In such cases, themes or categories reflecting the purpose of the research can be created by the researcher in advance, and these themes will act as the main categories in which the analysis is made (Yildırım and Şimşek, 2008). In this study, four different themes were determined beforehand. These themes were "scenes compatible with the learning outcomes of the course", "scenes incompatible with the learning outcomes of the course", "dialogues compatible with the learning outcomes of the course" and "dialogues in compatible with the learning outcomes of the course". The films were watched in terms of these themes, and the codes (scenes and dialogues) were determined.

\section{Findings}

This section explains the findings of the analysis of the films chosen as the sample of the study in terms of the moral learning outcomes for the secondary curriculum for the Religious Culture and Moral Knowledge Course.

\section{Assessment of Miracle in Cell No 7 in terms of the moral learning outcomes in the curriculum for the Religious Culture and Moral Knowledge course for secondary education}

This section explains the findings of the document analysis of Miracle in Cell No 7 in terms of the learning outcomes for the curriculum for the secondary Religious Culture and Moral Knowledge course. Table 2 gives four themes previously determined in accordance with the purpose of the study and the results of the analysis of these themes.

Table 2. Scenes and dialogue from Miracle in Cell No 7 that are compatible/incompatible with the moral learning outcomes in the secondary curriculum for the Religious Culture and Moral Knowledge course

\begin{tabular}{|c|c|c|c|}
\hline $\begin{array}{l}\text { Theme } \\
\text { No }\end{array}$ & Themes & Codes & $\mathbf{f}$ \\
\hline \multirow[t]{20}{*}{1} & Scenes found to be compatible with the learning outcomes & Love of a child & 23 \\
\hline & of the course (89) & Speaking of love & 17 \\
\hline & & Helping the weak & 12 \\
\hline & & Protecting the weak & 9 \\
\hline & & Respect for differences & 6 \\
\hline & & Praying & 3 \\
\hline & & Believing that every cloud has a silver & 2 \\
\hline & & lining & \\
\hline & & Explaining verses/suras & 2 \\
\hline & & Believing in destiny & 2 \\
\hline & & $\begin{array}{l}\text { Believing that doing harm to people is } \\
\text { sin }\end{array}$ & 2 \\
\hline & & Writing off each other's debts & 2 \\
\hline & & Taking only what is deserved & 2 \\
\hline & & Working hard & 1 \\
\hline & & Self-acceptance & 1 \\
\hline & & Importance of the family & 1 \\
\hline & & Reading books & 1 \\
\hline & & Use of guns (arbitrary) & 1 \\
\hline & & Patriotism & 1 \\
\hline & & Being at peace with life & 1 \\
\hline \multirow[t]{2}{*}{2} & Scenes found to be incompatible with the learning & Mocking others & 9 \\
\hline & outcomes of the course (36) & Beating & 8 \\
\hline
\end{tabular}


Dialogues found to be compatible with the learning outcomes (7)
Dialogues found to be incompatible with the learning outcomes (69)

\begin{tabular}{ll} 
Oppressing the weak & 5 \\
Despising others & 4 \\
Despising subordinates & 3 \\
Smoking & 3 \\
Wanting to kill others & 3 \\
Telling people to do forbidden things & 2 \\
Threats & 2 \\
Drinking alcoholic beverages & 1 \\
Considering oneself equal to Allah & 1 \\
(commander) & \\
Thinking that Allah's power is not & 1 \\
enough & \\
Slander & 1 \\
Jealousy & 1 \\
Murder & 1 \\
Running away from one's duty & 1 \\
Performing an act of kindness in & 2 \\
response to a sin & \\
Apologising & \\
Believing that theft is sin & 1 \\
Believing that lie is sin & 1 \\
Believing that repentance is necessary & 1 \\
Believing that Allah forgives & 1 \\
Slang & 1 \\
Insults & 28 \\
Lies & 1 \\
Thack of respect of differences & 1 \\
Wanting to commit suicide & \\
\hline
\end{tabular}

Examining Table 2, the theme of scenes in Miracle in Cell No. 7 found to be compatible with the moral learning outcomes included in the secondary curriculum of the Religious Culture and Moral Knowledge course includes 19 different scenes, and the total number of instances in this theme was 89. The film had the highest number of scenes in relation to "love of a child" ( $\mathrm{f}=23)$, which is followed by "speaking of love" ( $\mathrm{f}=17)$, "helping the weak" ( $\mathrm{f}=12)$, "protecting the weak ( $\mathrm{f}=9$ ), "respecting for differences" ( $\mathrm{f}=6$ ), "praying" ( $\mathrm{f}=3$ ). Also, although fewer in number there were morally important scenes including the ideas "believing that every cloud has a silver lining $(\mathrm{f}=2)$, "explaining verses/suras" ( $\mathrm{f}=2)$ "believing in destiny" $(\mathrm{f}=2)$, "believing that doing harm to people is a $\sin$ " $(\mathrm{f}=2)$, "writing off each other's debts" ( $\mathrm{f}=2)$ and "taking only what is deserved" $(\mathrm{f}=2)$. In order to emphasize the low number of elements that can be counted from moral gains due to the scope and aim of the research, low frequency codes are especially included in all tables.

In terms of the second theme, 16 scenes in Miracle in Cell No. 7were found incompatible with the moral learning outcomes included in the secondary curriculum for the Religious Culture and Moral Knowledge course, and a total frequency of 36 . Under this theme, scenes including "mocking" ( $\mathrm{f}=9)$ were the most common, followed by scenes of "beating" ( $\mathrm{f}=8$ ), "oppressing the weak" ( $\mathrm{f}=5)$, "despising others" $(\mathrm{f}=4)$, "despising subordinates" ( $\mathrm{f}=3)$, "smoking" ( $\mathrm{f}=3$ ) and "wanting to kill others" ( $\mathrm{f}=3$ ). 
Considering the theme of dialogues compatible with the moral learning outcomes included in the secondary curriculum for the Religious Education and Moral Knowledge course, it is seen that this theme includes six different compatible dialogues, and the total frequency was seven. Although "performing an act of kindness in response to a $\sin ^{\prime \prime}(\mathrm{f}=2)$ is the most common scene, the frequency is not high enough for both the dialogues and the theme.

Considering the theme of dialogues found to be incompatible with the moral learning outcomes included in the secondary curriculum for the Religious Culture and Moral Knowledge course, it is seen that this theme includes eight different instances of incompatible dialogues, and the total frequency is 69. The most common form of dialogues in the film in this regard is "slang" ( $\mathrm{f}=28)$, followed by "swearing" ( $\mathrm{f}=11$ ), "insults"( $f=11)$, "lies" ( $f=8)$ and "lack of respect for differences" ( $f=5)$. The frequency of dialogues including slang, swearwords and insults is striking.

\section{Assessment of Money Trap in terms of the moral learning outcomes for the curriculum of the Religious Culture and Moral Knowledge course for secondary education}

This section explains the findings of the document analysis of Money Trap in terms of the learning outcomes included in the secondary curriculum for the Religious Culture and Moral Knowledge Course. Table 3 shows the four themes previously determined in accordance with the purpose of the study, and the results of the analysis of these themes.

Table 3. Scenes and dialogues in Money Trap that are compatible/incompatible with the moral learning outcomes in the secondary curriculum for the Religious Culture and Moral Knowledge course

\begin{tabular}{|c|c|c|c|}
\hline $\begin{array}{l}\text { Theme } \\
\text { No }\end{array}$ & Themes & Codes & f \\
\hline \multirow[t]{12}{*}{1} & \multirow{12}{*}{$\begin{array}{l}\text { Scenes found to be compatible with the learning } \\
\text { outcomes (34) }\end{array}$} & Respect of elders & 9 \\
\hline & & Love of a child & 5 \\
\hline & & Encouraging kindness & 5 \\
\hline & & Respect for public officials & 3 \\
\hline & & Helping each other & 3 \\
\hline & & Trust in people & 2 \\
\hline & & Believing that every cloud has a silver lining & 2 \\
\hline & & Trust in public officials & 1 \\
\hline & & Empathy & 1 \\
\hline & & Greeting others & 1 \\
\hline & & Keeping a promise & 1 \\
\hline & & $\begin{array}{l}\text { Writing off each other's debts (although in } \\
\text { exchange for money) }\end{array}$ & 1 \\
\hline \multirow[t]{12}{*}{2} & \multirow{12}{*}{$\begin{array}{l}\text { Scenes found to be incompatible with the learning } \\
\text { outcomes }(70)\end{array}$} & Violence (beating) & 12 \\
\hline & & Alcoholic beverages & 9 \\
\hline & & Inappropriate clothes & 8 \\
\hline & & Fraud & 5 \\
\hline & & Eating in an impolite manner & 5 \\
\hline & & $\begin{array}{l}\text { Trying to get what one is owed in an unlawful } \\
\text { manner }\end{array}$ & 4 \\
\hline & & Dancing in a sexual manner & 3 \\
\hline & & Taking pride in immoral acts & 3 \\
\hline & & Gossip & 3 \\
\hline & & Gambling & 3 \\
\hline & & Bribery & 3 \\
\hline & & Failure to take responsibility & 2 \\
\hline
\end{tabular}


Dialogues found to be compatible with the learning outcomes (6)

Dialogues found to be incompatible with the learning outcomes (98)

\begin{tabular}{ll} 
A woman giving a man a foot massage (not as & 1 \\
part of her job) & \\
Yelling & 1 \\
Disrespect of elders & 1 \\
Not giving money & 1 \\
Treating or looking at women improperly & 1 \\
Encouraging evil & 1 \\
Using guns & 1 \\
Obscene language & 1 \\
Theft & 1 \\
Smoking & 1 \\
Chewing gum noisily & 1 \\
Refraining from swearing & 4 \\
Trying not to upset loved ones & 1 \\
Lying is bad & 1 \\
Slang & 41 \\
Lying & 26 \\
Swearing & 15 \\
Threats & 8 \\
Falsely swearing an oath & 4 \\
Praising people who do not deserve it & 2 \\
Encouraging evil & 1 \\
Sexuality & 1 \\
\hline &
\end{tabular}

Table 3 shows the scenes in Money Trap that are compatible with the moral learning outcomes of the secondary curriculum for the Religious Culture and Moral Knowledge. This theme includes 12 different scenes, and the total frequency is 34 . The most common scenes compatible with the moral learning outcomes are "respect to the elders" ( $\mathrm{f}=9$ ), "love of a child" ( $\mathrm{f}=5$ ) and "encouraging kindness" ( $\mathrm{f}=5$ ).

With regard to scenes incompatible with the moral learning outcomes in the secondary curriculum for the Religious Education and Moral Knowledge Course, this theme includes 23 different incompatible scenes, and they are repeated 70 times in total. The most common scenes incompatible with the moral learning outcomes involved "violence (beating)" ( $\mathrm{f}=12)$, followed by scenes with "alcoholic beverages" ( $\mathrm{f}=9$ ), "inappropriate clothes" ( $\mathrm{f}=8)$, "fraud" $(\mathrm{f}=5)$, "Eating in an impolite manner" ( $\mathrm{f}=5$ )and "Trying to what one is owed in an unlawful manner" ( $\mathrm{f}=4$ ) scenes. It is noteworthy that since the film is an action comedy, such scenes are quite comical and the characters in the scenes are often very sympathetic or funny.

The dialogues in Money Trap that is compatible with the moral learning outcomes in the secondary curriculum for the Religious Culture and Moral Knowledge course includes three different dialogues, and the total frequency of the codes is six. The most frequent form of dialogues compatible with the moral learning outcomes is "refraining from swearing" ( $\mathrm{f}=4)$ and its frequency is low. The other two forms of dialogues compatible with the moral learning outcomes of the course are "trying not to upset loved ones" ( $\mathrm{f}=1$ ) and "lying is bad" ( $\mathrm{f}=1)$. The low frequencies of these forms of dialogues are striking.

Lastly, the theme related to dialogues incompatible with the moral learning outcomes in the secondary curriculum for the Religious Culture and Moral Knowledge course for secondary education, includes eight different dialogues, and the total frequency of the codes is 98 . Among the dialogues incompatible with the moral learning outcomes, the most frequent form is "slang" ( $\mathrm{f}=41)$ and its frequency is high. This is followed by "lying" ( $\mathrm{f}=26)$, "swearing" ( $\mathrm{f}=15)$, "threats" ( $\mathrm{f}=8$ ) and "falsely swearing an oath" $(\mathrm{f}=4)$. It is noteworthy that 
the frequencies of lying and swearing are high. The use of slang in the film stands out; almost all of the characters use slang in their ordinary speech.

\section{Discussion}

This study conducted examined the two most watched films in 2019 in Turkey (Miracle in Cell No. 7 and Money Trap) in terms of the moral learning outcomes included in the secondary curriculum for the Religious Culture and Moral Knowledge course. It found that there were both positive and negative scenes in the films examined. Likewise, there were both positive and negative dialogues. However, there were more negative scenes and dialogues than positive ones. Based on the fact that people learn $10 \%$ of what they read, $20 \%$ of what they hear, $30 \%$ of what they see, $50 \%$ of what they see and hear, $80 \%$ of what they see, hear and say, and $90 \%$ of what they see, hear, touch and say (Demirel, 2002), these films may make it easier to learn negative things. Cinema is the art form that reaches the masses most easily and is most easily understood; it affects people through its dramatic structure, creates a kind of collective consciousness and can easily manipulate people (Yanmaz, 2011).

With regard to both films, the actors playing the leading roles have a high impact. They have between three and six million followers on social media. In a study conducted by Erjem and Çağlayandereli (2006) to examine the effects of a TV series on the behaviours of young people, approximately $72 \%$ of the participants stated that they saw specific characters in the TV series as role models. It was also determined in the study that not all of the behaviours seen on screen provided good examples. Given the impact of cinema, as well as the actors playing the characters, it seems inevitable that young people will take up or imitate the negative ways of speaking and behaviours that they see in films.

Every activity that has an aesthetic concern can in some sense be described as 'art'. One of the main tasks of art is to educate people through entertainment. (Atmaca, 2008; Moran, 2003). Seeking for and grasping the beauty is the way to overcome evil in the world. Having an aesthetic consciousness means being an individual who can speak, know, write, and act well (Kavcar, 1999). Emphasizing the moral aspect of art, Durkheim (cited in Gençaydın, 2002) states that people whose emotions are fed by the pleasure of aesthetic values will not put aside moral values and are not able to think in an evil way. In this regard, films with higher moral values may serve to aid the development of aesthetic awareness. Learning cannot be considered separately from life and social environment although the acquisition of moral values within the education system is one of the aims of education. It is important that the moral values that are desired to be brought into the individual are in life (Tabak and Ahi, 2020). Films should not only be considered as being able to supplement the teaching tools but should also be considered as teaching and educational tools themselves (Birkök, 2008). In fact, films can be used to make paradigm shifts occur in education (Yıldırım, Tüzel and Yar Yıldırım, 2016). In this way, it may be possible to help people to improve themselves. Education is a system that should help people develop their inherent skills and find their own paths (Robinson and Aronica, 2018).

\section{Conclusions and Recommendations}

On the basis of the findings of this study, which assessed the two most watched Turkish films of 2019 in terms of the moral learning outcomes included in the secondary curriculum for the Religious Culture and Moral Knowledge course, it was concluded that:

In Miracle in Cell No. 7, there were 96 instances of scenes and dialogues that were compatible with the moral learning outcomes of the course, while 105 that were incompatible. It is noteworthy that there were more incompatible scenes or dialogues although the film is a drama. The use of slang, swearwords and insults were the main forms of speech which were incompatible in terms of the moral learning outcomes. The film, which is a drama, sold 5,310,542 tickets, and thus has a significant audience impact. 
In Money Trap, there were 42 instances of scenes and dialogues compatible with the moral learning outcomes, and 168 that were incompatible. In other words, the ratio of compatible scenes and dialogues to incompatible ones was $1 / 4$. Scenes of beatings, and dialogues involving the use of slang, lying and swearing dialogues were frequently repeated. In both films studied, slang was the most common form of speech incompatible with the moral learning outcomes. The characters in this film are sympathetic and these scenes are funny, and it is thought that these features of the film increased its impact on the mass audience.

The following recommendations can be made on the basis of the findings of this study:

- Cinema has a large impact as a branch of art that includes sound, visual elements, music, lighting etc. Families or schools may not have the same effect, because families and schools represent real life; they are not an imaginary world. In this regard, activities should be carried out to raise the awareness of families and education professionals about the impact of the external world on education. Likewise, activities to increase the awareness of those working in cinema about educational learning outcomes could be carried out so that informal and formal modes of education are not negatively affected.

- Film scripts might be reviewed by the Board of Education and Discipline.

- Films with an abundance of visual elements and dialogues compatible with educational learning outcomes might be rewarded by the Board of Education and Discipline. They could also be promoted.

- The learning outcomes in the curricula could be integrated into scenes and dialogues with the aim of serving the overall purpose of education. 


\section{REFERENCES}

Akpınar, N. (Producer) \& Erdoğan, Y. (Director). (2019). Organized Works Money Trap [Movie]. Turkey: BKM Film.

Alp, H. \& Turan, E. (2019). Analysis of Recep Ivedik Film 5 in terms of violence in popular culture. Karabuk University Journal of Institute of Social Sciences, 9(1), 28-40.

Atmaca, A. E. (2008). The necessity of art education in social life and the role of media. Family and Society, 15(15), 21-28.

Ayar, S., Turan, S. (Producer) \& Öztekin, M. A. (Director). Miracle in Cell No:7 [Movie]. Turkey: Lanistar Media.

Birkök, M. C. (2008). Alternate media usage in education as a socialization tool: Movie. Journal of Human Sciences, 5(2), 1-12.

Boxoffice, 2020. All movies in 2019. https://boxofficeturkiye.com/turk-filmleri/?yil=2019. Date of access: 06.03 .2020

Büyükokutan Töret, A. (2014). A popular culture comedy: "Recep Ivedik"'. Proceedings of the International Symposium on Culture and Identity from the Window of the 21st Century, 26-28 May 2014, 68.

Can, N. \& Yıldırım, N. (2019). Teaching profession and aesthetics. G. Bedir and V. Yar Yildırım (Ed.) In Artistic variables of the teaching profession. (p. 43-70). Ankara: Pegem.

Demirel, Ö. (2002). The art of teaching from planning to assessment. Ankara: Pegem.

Elmac1, T. (2013). Reproduction of melodrama in context of Kader and Masumiyet films. Journal of World of Turks, 5(2), 261-277.

Erdem, A. R. (2003). An important factor in university culture: Values. Journal of Values Education, 1(1) 55-72.

Erjem, Y. \& Çağlayandereli, M. (2006). Television and youth: The effects of national television serials on the role modelling behaviours of youngsters. CU Journal of Social Sciences, 30(1), 15-30.

Geçgin, E. (2018). 'Arif' and 'Recep Ivedik' characters with regard to cultural differentiation. Gender E Cultural Studies, 183.

Gençaydın, Z. (2002). The place and current status of Gazi Education Faculty Art Teaching Department in training art educators. In Gazi University "1 ${ }^{\text {st }}$ Art Education Symposium" (p.25-30). Ankara.

Gök, C. (2007). Cinema and reality. Journal of Social Sciences, 1(2), 112-123.

http://www.beyazperde.com/filmler/film-275065/. Date of access: 08.03.2020

https://biletinial.com/sinema/yedi-numarali-hucredeki-mucize Date of access: 10.03.2020

https://www.netflix.com/browse/genre/1133133?jbv=81076251andjbp=4andjbr=21.Date of access: 08.03.2020

Kaşkaya, A., Ünlü, İ., Akar, M.S. \& Sağırlı, M.Ö. (2011). The Effect of school and teacher themed movies on pre-service teachers' professional attitudes and perceived self-efficacy. Educational Sciences: Theory $\mathcal{E}$ Practice, 11(4), 1765-178.

Kavcar, C. (1999). Literature and education (2. Ed.). Ankara: AU Faculty of Education Publications.

Kuçuradi, I. (1995). Education in terms of philosophy and education in Turkey, 17-18 November: Philosophical Society of Turkey, İstanbul. 
Miles, M, B., \& Huberman, A. M. (1994). Qualitative data analysis: An expanded sourcebook. (2nd ed). Thousand Oaks, CA: Sage.

Montagu, A. (2000). Helping children develop moral values. Ankara: Ministry of National Education.

Moran, B. (2003). Literary theories and criticism. İstanbul: İletişim.

National Education Basic Law (1973). https://www.mevzuat.gov.tr/MevzuatMetin/1.5.1739.pdf. Date of access: 03.03.2020.

Nowell-Smith, G. (1996). The Oxford history of world cinema. New York: Oxford University Press.

Okur, A., Süğümlü, Ü. \& Göçen, G. (2013). The impact of book to film adaptations on reading tendencies of secondary school, high school, and university students. The Journal of International Social Research, 7(33), 667-685.

Oruç, Ş. \& Sarıbudak, D. (2015). Opinions of school administrators and teachers regarding the effects of educational films on education environment. International Journal of Field Education, 1(1), 19-41.

Özbulduk Kılıç, I. (2018). The motivations that effect the movie selection of audience experience and the reception of movies: the example of Recep Ivedik. TRT Academy, 3(5), 322-321.

Özgener, Ş. (2004). The fundamentals of business ethics: A managerial approach. Ankara: Nobel.

Robinson, K. \& Aronica, L. (2018). The Element: How finding your passion changes everything (2. Ed.). (Translated by D. Boyraz). Istanbul: Sola.

Saral Güneş, S. \& Yağız Baylan, D. (2016). Cinema reflecting the consequences of social changes: the changing social structure and comedy films. Global Media Journal: Turkish Edition, 6(12), 332-355.

Tabak, H \& Ahi, B. (2020). Epistemic beliefs and expectations for gaining moral values from the education system. Kastamonu Education Journal, 28(2), 1054-1066. DOI: 10.24106/kefdergi.692691.

TDK (2005). Turkish dictionary. Ankara: Turkish Historical Society.

TDK (2020). Turkish Language Association Dictionaries. http://sozluk.gov.tr/. Date of access: 02.03.2020

TTK (2018). Curriculum of Religious Culture and Moral Knowledge Course. http://mufredat.meb.gov.tr/Programlar.aspx. Date of access: 29.03.2020

Vincenti, G. (1993). A hundred years of cinema. İstanbul: Evrensel.

Yakar, H. G. İ. (2013). The use of films for educational purposes: a historical assessment. Journal of Hasan Ali Yucel Education Faculty, 19(1), 21-36.

Yanmaz, P. (2011). The role of cinema in presentation of tourism. Gumushane University e-Journal of Faculty of Communication, 2, 112-139.

Yıldırım, A. ve Simsek, H. (2008). Qualitative research methods in social sciences. Ankara: Ekin.

Yıldırım, N., Tüzel, E. \& Yar Yıldırım, V. (2016). An educational study on Aamir Khan's movies: a qualitative investigation of 3 Idiots and Taare Zameen. Ataturk University Journal of Fine Arts Institute, (36), 210-244.

Yolcu, E. (2007). The effect of smoking scenes in the films on starting smoking. Istanbul University Journal of Communication Sciences, 26, 139-150. 